\title{
Developing Comic Media Carrying Character Building to Teach an Introduction to Accounting for Students of Vocational High School
}

\author{
Benedecta Indah Nugraheni \\ Rita Eny Purwanti \\ Teacher Training and Education Faculty \\ Universitas Sanata Dharma \\ Yogyakarta, Indonesia \\ ben_indah@usd.ac.id
}

\begin{abstract}
This research was aimed to develop an educational product in a form of comic books carrying character building that were used as the appropriate media for learning An Introduction to Accounting for Grade X students of Vocational High School (VHS), taking the area of expertise in Business and Management.

The comic books were developed through a Research and Development ( $R$ and $D)$. The procedure of the research adopted the steps of system approach to instructional learning program design by Dick and Carey. This research carried out nine steps of $R$ and $D$ starting from Identifying Instructional Goals to Formative Evaluation. The Formative Evaluation was conducted in expert validation and trials. The subjects of trials were the Grade $X$ students of vocational high school. The data was collected by the use of questioners and interviews. The data were quantitative and qualitative in nature. The quantitative data were resulted from the assessments of the comic books. The qualitative data were in a form of the suggestions or comments to improve the designed product. Both of data were analyzed descriptively.

The result of this research showed that the comic books were appropriate to be used as a media for An Introduction to Accounting learning. This is showed by the result of: (1) the validation from the expert in materials with an average score of 4.69 that was categorized as "very good"; (2) the validation from the expert in media with an average score of 4.15 that was categorized as "good"; (3) the validation from the expert in character building with an average score of 4.93 that was categorized as "very good"; (4) the validation from the accounting teachers with an average score of 4.39 that was categorized as "very good"; (5) one-on-one trials with an average score of 4.26 that was categorized as "very good"; (6) small group trials with an average score of 4,22 that was categorized as "very good"; (7) field trials with an average score of 4,22 that was categorized as "very good". In addition, the average value of the students' responses to the comic book as a learning media showed the "very good" category with an average score of 4,25.
\end{abstract}

Keywords; developing, media, comic, character building, accounting, and vocational high school

\section{INTRODUCTION}

The availability of learning media and resources for the Indonesian students of Vocational High School (VHS) specializing in Business and Management was relatively low. This also happened to Accounting courses. The existing materials were in a form of textbooks that were limited and had uninteresting presentation. In the mean time, students perceived that accounting was one of difficult subjects that consisted of counting operation jobs. However, accounting consists of concepts and logical thinking.

In the current high school curriculum, student learning focuses on not only cognitive but also affective aspects. This is implemented, one of them, in the development of students' attitude and character. Whereas, the available learning resources only focused on developing cognitive aspects and skills and paid less attention to affective aspects.

Based on that reality, there was a need to develop innovative and motivating learning media to teach accounting. In order to fulfill this need, we developed learning media to teach accounting in a form of comics. It was hoped that these learning media would build the students' positive attitude toward learning accounting. Therefore, the comic media that were developed in this research comprise not only accounting materials that would develop knowledge and skills but also learning contents that develop students' character, namely, responsibility, honesty, discipline, and carefulness as they are mentioned in the curriculum.

The development of comic media was based on the assumption that the VHS students who are teenagers like reading comic books [1]. Comic books are popular both among adult and young people including students [2] [3].This happens because comics provide various and interesting presentations, have relaxing and entertaining contents, so that they are not boring to read by everyone.

Comics can also be utilized as media for learning that the students can make benefits from them [4]. It is mentioned in some articles that comics as learning media have many advantages. They can be used for any level of education and 
help to improve the learning effectiveness. They can develop critical-literacy skills they need to negotiate diverse systems of meaning making [2][3][5]. This makes the students more interested to read and easier to understand the contents.

Media consisting comics are perceived to be able to motivate the students in learning a variety of subjects [6]. Therefore, it is hoped that learning using comic media, VHS students, who are beginners in accounting learning, have higher motivation and positive attitude in learning accounting.

It is expected that this development of comic media for accounting learning would provide a new perspective in the development of learning media and trigger more innovative and motivating media development.

\section{StATE-OF-THE-ART}

There are several articles that discuss the utilization of comics for classroom learning media. Trent dan Kinlaw, in their study, pointed out that comics had been used effectively with children in the classroom for decades [7]. Attitudes toward the comic book as an educational medium were generally positive. Morrison, Bryan, and Chilcoat stated that by designing their own comic books teachers could help students develop their writing, comprehension, and research skills. Designing a comic book provides an opportunity for students to be creative in presentation of their writing. Using comic books will enhance instructions in comprehension strategies. This approach also offers students an opportunity to refine their research skills [1]. Lawson gave a few examples to illustrate how comic strips were used to teach economic principles [8]. Jacobs found out that reading comics involves a complex, multimodal literacy; and using comics in the classroom, teachers can help students to develop themselves as critical readers of multimodal texts. Teacher can also help students to become active creators, rather than passive consumers, of meaning in their interactions with a wide variety of multimodal texts [5].

Gerde and Foster used comic books to teach business ethics. They argued that comic books are a legitimate literary form for study and are used in teaching business ethics and business-and-society topics in the classroom. In addition, comic books are a modern form of narrative and can be effective in teaching the complexities and social context of specific topics [4]. In his article, Herbst argued that comics can be a semiotic resource for the creation of representations of teaching that can be used in teacher education [9]. Sardone use comic books to teach classic literature. She created the assignments to engage pre-service teachers in designing instructional materials that benefit today's students to help them overcome hurdles when learning classic literature [10].

Those articles share similarities in the perception that comic can be used as effective learning media for classroom activities. Therefore, the authors utilized them in developing the learning media in a variety of ways. In the meantime, some of them asked the students to develop comics as one of learning projects in order to develop comprehension, writing and research abilities.

Identify applicable sponsor/s here. (sponsors)
In Indonesia, the development and utilization of comic have been done by many teachers and researchers. They have developed comic media for learning in a variety of subjects, such as Physics, Biology, Mathematics, Geography, Chemistry, Accounting, etc. One of them was developed by Elis Mediawati as a result of her research in the utilization of comic media for teaching accounting, published in Jurnal Penelitian Pendidikan (Journal of Educational Research) entitled "Pembelajaran Akuntansi Keuangan Melalui Media Komik untuk Meningkatkan Prestasi Mahasiswa" (Learning Accounting through Comic Media to Improve the Students' Learning Achievements). The study found out that (1) Students showed good responses toward comic media utilized in learning accounting in the classroom, and (2) the students' learning achievements, obtained through the learning process that utilized comic media showed significant, increased [11].

Concerning this research that we conducted, it had two major differences compared with the previous researches. First, the difference lies in the purpose. While the previous researches aimed at seeing the effectiveness from the implementation of the comic media, this research aimed at developing the comic media as an educational product through Research and Development. As a consequence, the research methods were also different. Second, while the previous targeted on the students' achievements, our research focused on the content development in which the comic media carry out the character education for the Grade $\mathrm{X}$ of accounting students of VHS specializing in Business and Management.

\section{Problem Statement}

This research had one major research question that was formulated as: "What is the design of comic media containing character building that is suitable for learning Introduction to Accounting for the Grade X students of VHS specializing in Business and Management?“‘

In specific, this question was broken down into several questions, namely:

1. What is the quality of the comic media in the aspect of materials?

2. What is the quality of the comic media in the aspect of media?

3. What is the quality of the comic media in the aspect of character building contents?

4. How do the students perceive on the utilization of comic media for learning accounting?

\section{PROPOSED APPROACH}

\section{A. Research Method}

This research utilized Research and Development as the research method. The research procedure adopted the steps of instructional program design suggested by Dick and Carey, 
which consisted of 10 steps, namely, (1) assess needs to identify goal (s), (2) conduct instructional analysis, (3) analyze learners and contexts, (4) write performance objectives, (5) develop assessment instruments, (6) develop instructional strategies, (7) develop and select instructional materials, (8) design and conduct formative evaluation of instruction, (9) Revise instructions, (10) design and conduct summative evaluation [11].

The step of formative evaluation was conducted in expert validations and product trials. The expert validation was conducted by experts in materials, media, character education, and VHS teachers. Then, the product was implemented in several trials, namely, one-on-one trial, small group trial, and field trial. The research subjects were the Grade X students of State-owned Godean 1 VHS and Sanjaya VHS, located in Sleman regency of Yogyakarta Special Province, and also State-owned VHS 1 of Yogyakarta and BOPKRI 1 VHS of Yogyakarta. The numbers of the students were 20 students in one on one trial, 39 students in small group trial, and 192 students in the bigger group of field trial.

The data was collected by the use of questioners and interviews. The data were quantitative and qualitative in nature. The quantitative data were resulted from the assessment of the comic book. The qualitative data were in a form of the suggestions or comments that were intended to improve the designed product. Both of data were analyzed descriptively. The result of product evaluation data analysis is converted from quantitative to qualitative data. Normal curve was used as the reference within 5 scales, as presented in Table 1.

TABLE I. DATA CONVERSION FROM QUANTITATIVE TO QUALITATIVE

\begin{tabular}{|c|c|}
\hline Interval Score & Criteria \\
\hline $\mathrm{X}>4,21$ & Very good \\
\hline $3,40<\mathrm{X} \leq 4,21$ & Good \\
\hline $2,60<\mathrm{X} \leq 3,40$ & Sufficient \\
\hline $1,79<\mathrm{X} \leq 2,60$ & Less than sufficient \\
\hline $\mathrm{X} \leq 1,79$ & Insufficient \\
\hline
\end{tabular}

\section{B. Research Result and Discussion}

After several steps of development were conducted, the product in a form of comic media was developed. The comic media were developed in four series, as follows:

1. Serie A: Accounting Equation

2. Serie B: Entry Journal Processing in Service Enterprise

3. Serie C: Ledger Processing in Service Enterprise

4. Serie D: Financial Statement Making in Service Enterprise
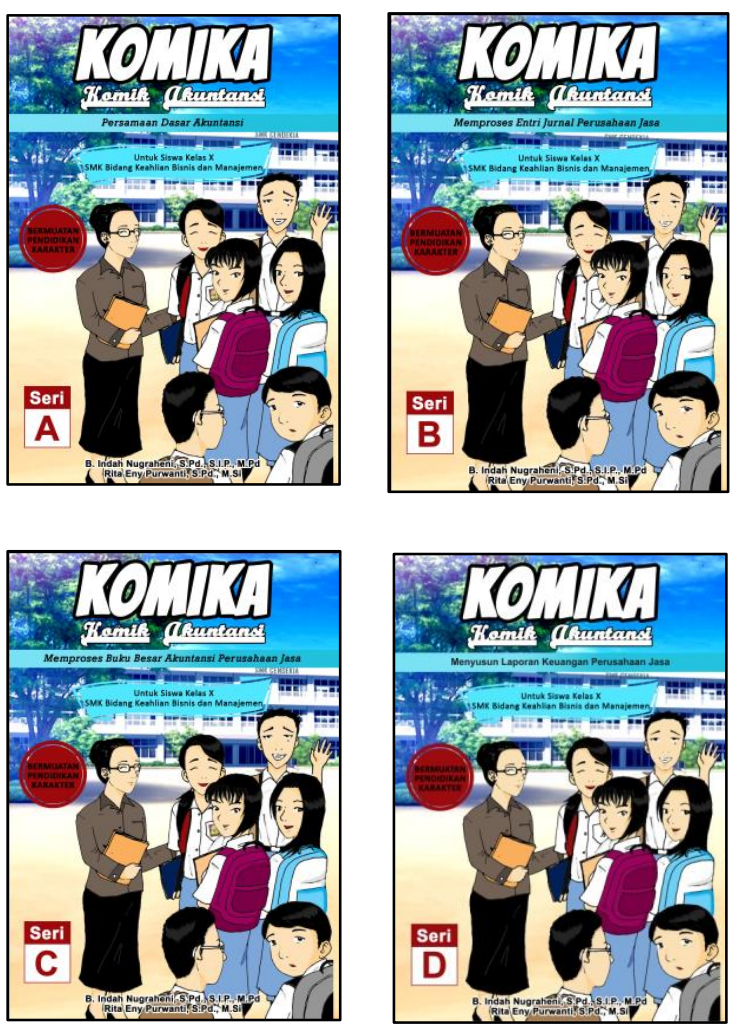

Figure 1. Four series of comic books.

The comic books consist of usage manual, learning materials containing character education, worksheets for exercises, reflection, and references. The followings are sample materials containing character education in the comic media.
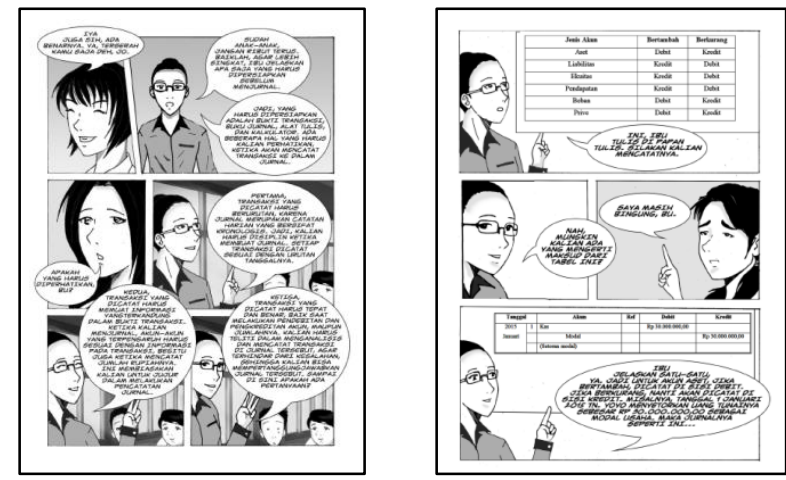

Figure 2. Sample materials containing character building.

After the product proto-type was developed, expert validations and product trials were conducted. The qualitative data in a form of comments and feedbacks were then used to revise the product. The revision was conducted in the aspects of contents, instructions, face validity, material presentation and language. The quantitative data of expert validations were analyzed using descriptive statistics. The result of analysis is presented in Table II, as follows. 
TABLE II. RESULT OF EXPERT VALIDATION

\begin{tabular}{|c|c|c|c|}
\hline \multirow{2}{*}{$\begin{array}{l}\text { Kinds of } \\
\text { Trials }\end{array}$} & \multicolumn{3}{|c|}{ Evaluated Aspects and Result } \\
\hline & Evaluated Aspects & $\begin{array}{l}\text { Average } \\
\text { Scores }\end{array}$ & Categories \\
\hline \multirow{3}{*}{$\begin{array}{l}\text { Expert in } \\
\text { material } \\
\text { development }\end{array}$} & Instructional (14 items) & 4.86 & Very good \\
\hline & Content (10 items) & 4.45 & Very good \\
\hline & Total average score & 4.69 & Very good \\
\hline \multirow{4}{*}{$\begin{array}{l}\text { Expert in } \\
\text { media }\end{array}$} & Face validity (9 items) & 4.06 & Good \\
\hline & Material presentation (5items) & 4.30 & Very good \\
\hline & Language (9 items) & 4.17 & Good \\
\hline & Total average score & 4.15 & Good \\
\hline $\begin{array}{l}\text { Expert in } \\
\text { character } \\
\text { education }\end{array}$ & $\begin{array}{l}\text { Character building content (10 } \\
\text { items) }\end{array}$ & 4.93 & Very good \\
\hline \multirow{7}{*}{$\begin{array}{l}\text { Accounting } \\
\text { Teacher }\end{array}$} & Instructional (14 items) & 4.37 & Very good \\
\hline & Content (10 items) & 4.33 & Very good \\
\hline & Face validity ( 9 items) & 4.40 & Very good \\
\hline & Material presentation (5items) & 4.48 & Very good \\
\hline & Language (9 items) & 4.35 & Very good \\
\hline & $\begin{array}{l}\text { Character building content (10 } \\
\text { items) }\end{array}$ & 4.46 & Very good \\
\hline & Total average score & 4.39 & Very good \\
\hline
\end{tabular}

a. Sample of a Table footnote. (Table footnote)

The product evaluation of the learning aspects and contents from the expert in material development showed the category of "very good". The evaluation showed that the overall average score was 4.69 having the category of "very good".

Expert in media evaluating the face validity and language gave the category of "good", while for material presentation the category was "very good". The average score for the overall aspects was 4.15 that belonged to the category of "good".

The aspect of character building was evaluated and determined as "very good" by the expert in character education with the average score of 4.93 .

Finally, the result of evaluation conducted by five accounting teachers showed that all aspects belong to the category of "very good". The average score also showed the same category as it showed 4.39.

Based on the result of product evaluation from all the validators and their feedbacks, the product of comic media were revised. The next step after the product revision was the product trials.
TABLE III. RESUlt OF PRODUCT TRIALS

\begin{tabular}{|c|c|c|c|}
\hline \multirow{2}{*}{$\begin{array}{c}\text { Kinds } \\
\text { of } \\
\text { Trials }\end{array}$} & \multicolumn{3}{|c|}{ Evaluated Aspects and Result } \\
\hline & Evaluated Aspects & $\begin{array}{l}\text { Average } \\
\text { score }\end{array}$ & Categories \\
\hline \multirow{7}{*}{$\begin{array}{l}\text { One on } \\
\text { one }\end{array}$} & Instructional (5 items) & 4.41 & Very good \\
\hline & Content (5 items) & 4.30 & Very good \\
\hline & Face validity ( 9 items) & 4.11 & Good \\
\hline & Material presentation ( 5 items) & 4.21 & Good \\
\hline & Language (6 items) & 4.22 & Very good \\
\hline & $\begin{array}{l}\text { Character building content (7 } \\
\text { items) }\end{array}$ & 4.38 & Very good \\
\hline & Total average score & 4.26 & Very good \\
\hline \multirow{7}{*}{$\begin{array}{l}\text { Small } \\
\text { Group }\end{array}$} & Instructional (5 items) & 4.26 & Very good \\
\hline & Content (5 items) & 4.21 & Good \\
\hline & Face validity ( 9 items) & 4.11 & Good \\
\hline & Material presentation ( 5 items) & 4.11 & Good \\
\hline & Language (6 items) & 4.18 & Good \\
\hline & $\begin{array}{l}\text { Character building content (7 } \\
\text { items) }\end{array}$ & 4.33 & Very good \\
\hline & Total average score & 4.20 & Good \\
\hline \multirow{7}{*}{ Field } & Instructional (5 items) & 4.30 & Very good \\
\hline & Content (5 items) & 4.23 & Very good \\
\hline & Face validity ( 9 items) & 4.10 & Good \\
\hline & Material presentation ( 5 items) & 4.13 & Good \\
\hline & Language (6 items) & 4.21 & Good \\
\hline & $\begin{array}{l}\text { Character building content (7 } \\
\text { items) }\end{array}$ & 4.36 & Very good \\
\hline & Total average score & 4.22 & Very good \\
\hline
\end{tabular}

In one-on-one trial, two aspects, i.e., face validity and material presentation resulted in "good" category, while the other aspects belonged to "very good" category. The total average score was 4.26 showing the "very good" category.

In small group trial, the instructional aspect and character building content were given "very good", while the other aspects belonged to the "good" category. The total average score was 4.20 belonging to the "good" category.

Finally, in the field trial, three aspects belonged to "good" categoryies, while the other three resulted in the "very good" category. Overall, from this trial the product was categorized as "very good" as it showed the total average score of 4.22.

In addition to data of product evaluation, the data were also taken from the students' responses to the implementation of the comic media that had been developed. The students' responses were gathered by the use of questionnaires. The data were represented by five Likert-scaled alternatives of answers. The following is the data of students' responses obtained from the product implementation. 
TABLE IV. STUDENT'S RESPONSE

\begin{tabular}{|c|c|c|c|}
\hline \multirow[b]{2}{*}{ Num } & \multicolumn{3}{|c|}{ Evaluated Aspects and Result } \\
\hline & Evaluated Aspects & $\begin{array}{c}\text { Average } \\
\text { score }\end{array}$ & Categories \\
\hline 1 & $\begin{array}{l}\text { The existence of comic media } \\
\text { for accounting learning. }\end{array}$ & 4.54 & $\begin{array}{l}\text { Definitely } \\
\text { agree }\end{array}$ \\
\hline 2 & $\begin{array}{l}\text { Students' learning preference } \\
\text { towards comic media and } \\
\text { textbooks }\end{array}$ & 3.85 & Agree \\
\hline 3 & $\begin{array}{l}\begin{array}{l}\text { Comic are more interesting } \\
\text { because of their variuos } \\
\text { properties } \\
\text { (pictures, }\end{array} \\
\text { conversations, and stories) than } \\
\text { the ones consisting only texts. }\end{array}$ & 4.33 & $\begin{array}{l}\text { Definitely } \\
\text { agree }\end{array}$ \\
\hline 4 & $\begin{array}{l}\text { Comic media motivate the } \\
\text { students in learning accounting. }\end{array}$ & 4.30 & $\begin{array}{l}\text { Definitely } \\
\text { agree }\end{array}$ \\
\hline 5 & $\begin{array}{l}\text { Learning materials of accounting } \\
\text { are easier to understand using } \\
\text { comic media. }\end{array}$ & 4.15 & Agree \\
\hline
\end{tabular}

a. Sample of a Table footnote. (Table footnote)

Most students claimed, "definitely agree" for the existence of comic media as the learning media in addition to textbooks. This statement reached the highest score of 4.54. It means that students supported the utilization of comic book as the learning sources beside textbooks. However, students' preference of comic media to textbooks only reached the category of "agree", reaching the lowest score of 3.85. It could be concluded that a number of students maintained that comic media became the supplementary learning sources to textbooks.

Most students claimed "definitely agree" that learning using comic media was more interesting because they were equipped with pictures, conversations, and stories to present materials instead of text only. This alternative way had made the students not to be bored when they learned from comic media. According to a number of students, comic media could also motivate them in learning accounting. Their agreements showed "definitely agree" towards the statement.

At last, students stated "agree" that they learned accounting materials more easily from comic media. This is in accordance with what Jacobs stated that comics engage multiple literacies [5]. As texts, comics provide a complex environment for the negotiation of meaning, beginning with the layout of the page it self. Images of people, objects, settings, word balloons, lettering, and gutters all come together to form page layouts that work to create meaning in distinctive ways and in multiple realms of meaning making.

Tha data obtained from the interviews indicated that students were interested in the use of comic media for learning accounting. They claimed that they could understand more easily and felt that learning was not boring. Meanwhile, teachers also felt happy because they were provided with an alternative learning source to teach accounting besides textbooks.

\section{CONCLUSION AND FUTURE WORK}

This research and development has developed an educational product in a from of comic media containing character education for accounting learning. The result showed that this product has been valid to be used as learning media for accounting learning for the Grade X of VHS. These comic media has been considered valid after the result of both product validation and trials showed the overall average scores showed categories of "good" and "very good". Besides, during the process of development this product was revised based on the feedbacks from the validators who were experts in their fields, teachers who were practitioners, and the students.

This research has conducted nine of ten steps of Research and Development. The last step, i.e., design and conduct summative evaluation, would be the next suggested research. This step is meant to conduct the effectiveness of the product to motivate the students in learning accounting and develop the students' characters.

\section{Acknowledgement:}

We would like to thank the Minister of Research, Technology, and Higher Education of Indonesia for funding this research.

\section{REFERENCES}

[1] T.G. Morrison, G. Bryan, and G. W. Chilcoat, "Using student-generated comic books in the classroom," Journal of Adolescent \& Adult Literacy, vol. 45, no. 8, pp. 758-767, May 2002.

[2] R. Versaci, "How comic books can change the way our students see literature: on teacher's perspective," The English Journal, vol. 91, no. 2, pp. 61-67, November 2001.

[3] S. Botzakis, "Adult fans of comic books: what they get out of reading," Journal of Adolescent \& Adult Literacy, vol. 53, no. 1, pp. 50-59.

[4] V .W. Gerde and R.S. Foster, "X-men ethics: using comics books to teach business ethics," Journal of Business Ethics, vol. 77, no. 3, pp. 245-258.

[5] D. Jacobs, "More than words: comics as means of teaching multiple literacies," The English Journal, vol. 96, no. 3, pp. 19-25.

[6] J. Berkowitz and T. Packer, "Heroes in the classroom: comic books in art education," Art education, vol. 54, no. 6, Learning to draw, pp. 1218, November 2001.

[7] C. Trent and R. Kinlaw, "Comic books: an effective teaching tool," Journal of Extension, pp. 18-23, January 1979.

[8] R.A. Lawson, "Teaching economic principles with comic strips," Journal of Private Enterprise, vol. XXII, Number 1, pp. 168-176, Fall 2006.

[9] P. Herbst, D. Chasan, C.L. Chen, V.M. Chieu, M. Weiss, "Using comics-based representations of teaching, and technology, to bring practice to teacher education courses," ZDM Mathematics Education, pp. 91-103, 2011.

[10] N.B. Sardone, "Teaching classic literature with comic books and virtual lit trips," The English Journal, vol. 102, no. 1, pp. 67-70, September 2012.

[11] E. Mediawati, "Pembelajaran Akuntansi Keuangan Melalui Media Komik untuk Meningkatkan Prestasi Mahasiswa," Jurnal Penelitian Pendidikan, vol. 12, no. 1, pp. 61-68, April 2011.

[12] W. Borg and M.D. Gall, Educational Research: An Introduction, New York: Longman, 2003, pp.570-571. 